\title{
Den ojämlika sjukfrånvaron Klass- och könsskillnader i sjukfrånvaro på 1990- och 2000-talet
}

\author{
OLOF BÄCKMAN, ANNA BRYNGELSON \\ \& OLLE LUNDBERG
}

\begin{abstract}
Trots en stundtals intensiv debatt om sjukfrånvarons orsaker och konsekvenser under de senaste 5-10 åren vet vi förhållandevis lite om hur sjukfrånvaron fördelar sig mellan olika socioekonomiska grupper. Artikeln syftar till att minska denna kunskapslucka. Vi analyserar sjukfränvarons fördelning och några orsaker till skillnader i sjukfrånvaro mellan olika klasser i början av 1990- respektive 2000-talet. Särskilt fokus riktas mot hur sjukfrånvarons socioekonomiska fördelning skiljer sig àt mellan män och kvinnor.
\end{abstract}

Människors välfärd bestäms av de resurser individerna har till sitt förfogande för att "...kontrollera och medvetet styra sina livsvillkor (se Johansson 1970 s. 25, även Fritzell \& Lundberg 2000). Dessa resurser är av

Olof Bäckman, docent i sociologi och forskare vid Institutet för Framtidsstudier i Stockholm.

Anna Bryngelson, fil. kand. i sociologi och forskningsassistent vid CHESS på Stockholms universitet/Karolinska institutet.

Olle Lundberg, professor i Health Equity Studies vid CHESS på Stockholms universitet/ Karolinska institutet. såväl materiell som immateriell natur, och inkluderar exempelvis utbildning, hälsa, inkomster, arbetsförhållanden, boendesituation, familj och sociala relationer. Över livets lopp används dessa resurser av individer och hushåll för att bibehålla eller förbättra sin välfärd. Hälsa är en central komponent i detta, dels eftersom hälsa i sig själv är en viktig aspekt av livet och högt värderad av de allra flesta (Oscarsson 2005), och dels för att en god hälsa är en viktig förutsättning för ett aktivt deltagande, inte minst $\mathrm{i}$ arbetslivet. 
De resurser individerna förfogar över består dels av genuint individuella resurser, men också resurser som skapas eller tillhandahålls genom familjen, marknaden och staten. Balansen mellan familj, marknad och stat vad gäller tillhandahållandet av resurser har kommit att bli en central skiljelinje mellan olika typer av välfärdsstater, där Sverige i likhet med andra nordiska länder har gett staten, eller snarare olika offentliga välfärdsinstitutioner, en viktig roll. Flera av dessa institutioner är på ett eller annat sätt kopplade till människors hälsa eller funktionsförmåga, och inte minst då inriktade på att hantera konsekvenser av sjukdom och nedsatt funktion. Här utgör sjukförsäkringen ett tydligt exempel - om arbetsförmågan sätts ner på grund av sjukdom, och därmed också möjligheten till försörjning via marknaden, träder sjukförsäkringen in. På så sätt bryts den onda spiral som uppkommer om sjukdom också leder till fattigdom, och i den meningen är sjukförsäkringen liksom de flesta andra socialförsäkringar ytterst en försäkring mot fattigdom. Men eftersom många skulle ha svårt att avstå från förvärvsarbete på grund av sjukdom om sjukförsäkringen inte fanns, så bidrar den, åtminstone i teorin, också till tillfrisknande.

Försäkringskassans uppgift är dock inte bara att betala ut sjukpenning. Man ska också utreda och betala ut sjuk- och aktivitetsersättning (f.d. förtidspension och sjukbidrag) vid mer bestående nedsättning av arbetsförmågan. Man har också det övergripande och samordnande ansvaret för rehabiliteringsinsatser för de sjukskrivna. Uppgiften här är att tillvarata resterande arbetsförmåga och utveckla denna i samar- bete med andra myndigheter och arbetsgivare. $^{1}$

Mellan 1996 och 2003 ökade sjukfrånvaron i Sverige dramatiskt. Inte minst mot denna bakgrund har sjukförsäkringen blivit alltmer omdebatterad under senare år. I samband med uppgången av sjukskrivningstalen tycks också sjukdomspanoramat ha skiftat, med bland annat tydliga tecken på ökade psykiska besvär. Samtidigt har även arbetslivets krav ökat, och det har uppenbarligen blivit allt svårare att återvända till arbetslivet efter en längre tids sjukskrivning (Socialstyrelsen 2006). En viktig skillnad mellan det sena 1990-talets sjukfrånvarokris och tidigare uppgångar av sjukskrivningstalen, som t.ex. den under slutet av 1980-talet, är att denna gång dominerar de långvariga sjukskrivningarna i påtagligt högre grad (a.a.). Detta gör utvecklingen under den senare perioden särskilt problematisk, dels därför att långvariga sjukskrivningar i högre grad än kortvariga representerar allvarligare hälsoproblem och kanske även utanförskap för de personer som det handlar om, men dels också därför att långtidssjukskrivningarna kan ses som en indikation på brister i sjukförsäkringens rehabiliterande funktion.

Givet att det är så att de som missgynnas av marknaden blir kompenserade av statens mer jämlika resursfördelning, kan vi förvänta oss att resurssvagare

1 För detaljerade uppgifter om sjukförsäkringens ersättningsnivåer, förändringar m.m. se http://www.forsakringskassan.se/omfk/socialforsakringen/historik/forandringar/dokument/ forandringar2005_01.pdf. 
grupper i praktiken får del av sjukförsäkringssystemets resurser i högre utsträckning än personer som är mer gynnade av marknadens fördelning. Därför kan vi också anta att det är de med mindre resurser i form av hälsa och goda arbetsförhållanden som har mest att förlora om sjukförsäkringen inte längre fungerar som den resurs den var avsedd att vara, utan i värsta fall till och med bidrar till marginalisering och passivisering (Bryngelson 2007). Således behöver vi en detaljerad och aktuell bild av hur hälsa, arbete och sjukförsäkring samverkar för olika grupper av människor. Samtidigt råder det brist på studier och statistik över fördelning av sjukskrivning mellan olika socioekonomiska grupper i Sverige samt dess eventuella orsaker.

I denna artikel har vi för avsikt att minska denna kunskapslucka genom att beskriva skillnader i sjukskrivning mellan olika socioekonomiska grupper för perioden 1991-2002 samt i vilken utsträckning mönstren skiljer sig åt mellan män och kvinnor. I en mer analytisk del försöker vi därefter att statistiskt förklara eventuella klasskillnader i långtidssjukskrivning (60 dagar eller mer) för män respektive kvinnor med hjälp av uppgifter om individers ålder, hälsa samt fysiska och psykiska arbetsförhållanden på arbetsplatsen. Dessutom undersöker vi om dessa förhållanden har förändrats sig mellan 1990-talets och 2000-talets inledning. Allra först diskuterar vi bakgrunden till studien lite mer i detalj, framför allt med avseende på hur arbete, hälsa och sjukskrivning hänger samman.

\section{Klass, kön och sjukfrånvaro}

Den klassmässiga fördelningen av sjukfrånvaron har $\mathrm{i}$ tidigare analyser påvisats ha ett $\mathrm{i}$ stort sett förväntat mönster, dvs. avtagande nivåer med stigande socialgruppstillhörighet. Mönstret har visat sig vara särskilt tydligt för män, men gäller även för kvinnor (Hemström 2000). Den mest uppenbara anledningen till att vi traditionellt sett har förväntat oss att finna detta mönster är att arbetsmiljön i arbetaryrken i allmänhet är mer krävande än i tjänstemannayrken. Detta bygger dock i mångt och mycket på en bild av fysiskt krävande arbetaryrken å ena sidan och tjänstemän med på alla sätt goda arbetsvillkor å den andra sidan. Det finns också anledning att förvänta sig att denna traditionella bild av utvecklingen i stora drag består. Samtidigt ser vi tecken på att den åtminstone till viss del håller på att förändras. De arbetsmiljöproblem som ökat under senare år är nämligen de psykosociala medan andelen som rapportera fysiska arbetsmiljöproblem stabiliserats (Socialstyrelsen 2005). Dessutom är det den psykiska ohälsan som ökat mest under de senaste årens sjukfrånvaroexplosion och den är inte alls lika tydligt kopplad till traditionella sjukdomsmönster inom arbetar- respektive tjänstemannayrken. Därför finns det också anledning att undersöka huruvida och i vilken mån klassmönstren för sjukfrånvaro har förändrats under de senaste 10-15 åren.

Om klassmönstren ändå skulle visa sig bestå är det ett minst lika viktigt resultat som om de inte gör det. Vi vet nämligen från andra studier (t.ex. Socialstyrelsen 2006) att personer med omfattande sjuk- 
frånvaro har små chanser att återkomma fullt ut i arbetslivet, även på lång sikt. Om dessutom den traditionella bilden av sjukfrånvarons fördelning består i tider av höga sjukfrånvaronivåer kommer sjukfrånvaron att bidra till en ökad skiktning i samhället. Det vill säga om det är så att de redan relativt sett resurssvagaste grupperna också är de som löper störst risk att drabbas av mer omfattande sjukfrånvaro, betyder det att en hög sjukfrånvaronivå bidrar till ökade skillnader i samhället.

Sjukfrånvaron är dock inte bara en enkel återspegling av skillnader i sjuklighet, utan bestäms i samspel mellan individens hälsotillstånd och arbetets krav. Detta framgår redan av lagtexten där det tydligt uttrycks att det inte är någon form av objektiv ohälsa som ska beaktas vid bedömningen av om en person är berättigad till sjukpenning utan i vilken grad arbetsförmågan är nedsatt på grund av ohälsa. Huruvida ett sjukdomstillstånd berättigar till sjukpenning beror alltså på vilket jobb man har. Skillnader i sjukskrivning mellan män och kvinnor eller sociala grupper bör därför idealt sett vara ett resultat av skillnader i såväl hälsotillstånd som arbetsförhållanden mellan dessa grupper.

Nicholson (1977) föreslår att man ska betrakta alla former av potentiellt frånvarogenererande händelser och tillstånd som placerade längs en skala där vi i den vänstra änden finner händelser där graden av "frivillighet« vad gäller huruvida händelsen leder till frånvaro från arbete eller inte är stor. Sådan frånvaro torde i förhållandevis liten utsträckning samvariera med ohälsa. Ju längre högerut på skalan vi rör oss desto mer "ofrivillig» blir frånvaron och desto mer kan vi förvänta oss att den orsakas av ohälsa (se också Bäckman 1998).

Ett och samma ohälsotillstånd kan dock komma att placeras vid helt olika positioner på skalan för olika personer beroende på bl.a. vilken typ av arbete man har. Exempelvis kommer ett benbrott för en byggnadsarbetare att hamna väldigt långt ut till höger på skalan medan det för en tjänsteman med utpräglat skrivbordsarbete hamnar betydligt längre till vänster. Den här modellen handlar dock framför allt om sambandet mellan fysiska ohälsotillstånd och sjukfrånvaron. Hur psykiska besvär placeras in längs en sådan skala är mindre uppenbart. Vi skulle mycket väl kunna tänka oss att psykiska besvär är mindre beroende av arbetsförhållanden när det gäller placering längs skalan utan att för den skull hävda att arbetsförhållanden inte är viktigt när det gäller uppkomsten av psykiska besvär. Den till Nicholsons modell närbesläktade sjukflexibilitetsmodellen har troligen bättre relevans när det gäller just huruvida psykiska sjukdomstillstånd leder till sjukfrånvaro. Här betonas hur graden av flexibilitet i arbetet, utryckt t.ex. som i vilken grad det är möjligt att arbeta hemma, påverkar i vilken utsträckning ohälsa leder till sjukfrånvaro i olika yrken. Modellen har fått visst empiriskt stöd i studier av Johansson och Lundberg (2004) respektive Johansson et al. (2006).

Tyvärr tillåter inte datamaterialets storlek att vi bryter ned det på den detaljnivå som skulle krävas för att testa i vilken mån sambandet mellan sjukfrånvaro och ohälsa varierar över olika typer av arbetsförhållanden. Resultaten skulle bli alltför osäkra för att medge att några slutsatser dras utifrån dem. Men genom att se vad som händer 
med klasskillnaderna när vi kontrollerar för hälsa får vi ändå en uppfattning om i vilken mån arbetsmiljöfaktorer bidrar till dessa skillnader.

Utöver klassdimensionen finns det dessutom en tydlig könsdimension i sjukfrånvaroutvecklingen. Kvinnor löper betydligt högre risk att hamna i omfattande sjukfrånvaro jämfört med män. Detta är i och för sig inget nytt fenomen. Kvinnornas sjuktal (antalet ersatta sjukdagar per år) passerade männens redan 1980 och har sedan dess legat högre. Under 1990-talets andra hälft ökade emellertid detta avstånd påtagligt. Det finns flera tänkbara orsaker till detta. En av dessa är att den snabbare sjukfrånvaroökningen bland kvinnor till viss del kan bero på ökad arbetsbörda inom den kvinnodominerade offentliga sektorn. Som nämndes ovan har inte klassmönstret för kvinnors sjukfrånvaro varit lika tydligt som för männen, vilket sannolikt delvis förklaras just av att flera stora kvinnodominerande tjänstemannayrken inom offentlig sektor kännetecknats av mer psykosociala arbetsmiljöproblem (Bäckman 2001). Vi kommer i denna studie inte närmare undersöka orsaker till kvinnors högre sjukfrånvaro. Vårt fokus ligger istället på skillnader mellan socioekonomiska grupper, men här ingår också en analys av i vilken grad dessa skiljer sig åt mellan könen.

I analyserna söker vi svar på följande frågor:

- Har sjukfrånvarons klassmönster förändrats under 1990-talet?

- Består könsskillnaderna när det gäller sjukfrånvarons klassmönster?

- I vilken mån kan skillnader i arbetsmiljö förklara sjukfrånvarons klassmönster?
- Har arbetsmiljöns förklaringskraft förändrats under 1990-talet?

- Speglar sjukfrånvarons klassmönster endast skillnader i hälsostatus?

\section{Data och metod}

Det datamaterial som vi använder i de statistiska analyserna består av intervjuuppgifter från levnadsnivåundersökningarna (LNU) 1991 och 2000. Till dessa har länkats uppgifter om registrerad sjukfrånvaro från Försäkringskassan. LNU genomförs vid Institutet för Social Forskning vid Stockholms universitet. LNU 1991 och 2000 är den fjärde och den femte undersökningen i ordningen. De tidigare genomfördes 1968, 1974 och 1981. Undersökningarnas syfte har varit att spegla levnadsvillkoren för befolkningen i Sverige. Detta har man gjort med hjälp av frågor kring nio olika välfärdsområden varav två handlar om hälsa (och vårdutnyttjande) respektive sysselsättning och arbetsvillkor (se t.ex. Fritzell et al. 2001, för ytterligare information om LNU). Det är således frågor från dessa två områden som vi kommer att använda oss av $i$ analysen.

LNUs mål är att intervjua ungefär var 1000e invånare i åldern 19-75 år. ${ }^{2}$ I och med det bortfall som varje undersökning av det här slaget får dras med uppnås inte detta mål fullt ut. LNU 1991 hade 20,9 procents bortfall och 2000 låg bortfallet på 23,4 procent. Undersökningarna avser dels

2 I de tre första undersökningarna var den nedre åldersgränsen 15 år, 199118 år och år 200019 år. 
ge en tvärsnittsbild av befolkningen, men har också en panelansats vilket innebär att exempelvis de som intervjuades 1991 och som fortfarande ingår i åldersintervallet samt lever och bor kvar i landet också ingår i urvalet 2000. Vissa personer i LNU kan man på så sätt följa genom alla fem undersökningarna.

I våra analyser har vi valt ut dem som var 20-59 år samt hel- eller deltidsarbetande veckan före intervjun 1991 respektive 2000. Eftersom egna företagare har speciella regler för sjukpenning har vi valt att utesluta den gruppen från analyserna. För 1991 års analysgrupp gäller dessutom att de måste ha ingått i urvalet för LNU 2000 för att ingå i analysen. Detta beror på att de sjukskrivningsdata vi har tillgång till är uttagna för 2000 års urval. Det här ger en viss positiv hälsoselektion till gruppen eftersom de som avled innan de hann delta i LNU 2000 inte ingår i analysen av urvalet 1991. Det innebär sannolikt att vi underskattar effekterna av arbetsmiljö och ohälsa något i denna analys. Totalt innebär våra urvalskriterier att vi för 1991 års analysgrupp har 1268 män och 1451 kvinnor. Motsvarande siffror för år 2000 är 1301 män och 1405 kvinnor.

Sjukskrivningsdata avser, som nämnts, sjukfrånvaro så som den registrerats hos Försäkringskassan. Vi använder oss av data från åren 1991-93 respektive 200002. Under flertalet av dessa år var den s.k. arbetsgivarperioden 14 dagar. Under dessa dagar är arbetsgivaren skyldig att betala sjuklön. Det här gör att uppgifter om sjukfrånvaron de första två veckorna av ett fall inte finns registrerade hos Försäkringskassan. För att kompensera för det har vi lagt till 14 dagar till alla sjukfall under de perioder då arbetsgivarperioden varit i bruk.

Eftersom vi framför allt intresserar oss för "ofrivillig» sjukfrånvaro, enligt Nicholsons resonemang som refererades ovan, har vi skapat en indikator på långvarig sjukskrivning. Vi har valt ett mått som indikerar om undersökningspersonen haft minst ett sjukfall om minst 60 dagar under aktuell period. Sjukfall om minst 60 dagar är också ett mått som ofta används som en sådan indikator, bl.a. i Försäkringskassans s.k. decemberundersökningar.

Vår huvudsakliga oberoende variabel är socioekonomisk grupp. Vi har delat in undersökningspopulationen i socioekonomiska grupper enligt Statistiska centralbyråns "socioekonomiska indelning" (SEI). De grupper vi urskiljer är: ej facklärda arbetare, facklärda arbetare, lägre tjänstemän, tjänstemän på mellannivå och högre tjänstemän inklusive fria akademikeryrken.

Vi kontrollerar för arbetsmiljö med hjälp av tre index som är tänkta att mäta exponering för ergonomiskt krävande, kemiskt/ fysiskt krävande samt psykiskt krävande arbetsmiljöer. Det ergonomiska indexet skapas utifrån fem frågor om huruvida man behöver kunna lyfta $60 \mathrm{~kg}$ i arbetet, om man blir svettig dagligen i arbetet, om man har mycket upprepade och ensidiga arbetsrörelser $\mathrm{i}$ arbetet, om man tvingas till olämpliga arbetsställningar samt om arbetet på något annat sätt är kroppsligt krävande. Om man svarar jakande på tre av dessa frågor får man värdet ett på variabeln »Ergo", annars noll. Vi kodar arbetet som kemiskt och på annat sätt fysiskt utsatt om man uppger minst två av tre arbetsmiljöproblem: att man åtminstone ibland är utsatt för öronbedövande buller, 
att man åtminstone ibland är utsatt för gas, damm eller rök samt att man åtminstone ibland kommer i kontakt med gift, syra eller explosiva ämnen. Variabeln „Kemfys» för då värdet ett, annars noll. Slutligen är arbetsmiljövariabeln »Psyk« skapad utifrån fyra intervjufrågor. Två av dessa avses mäta graden av krav i arbetet. Kravnivån i arbetet anses hög om intervjupersonen svarat att arbetet är både psykiskt krävande och jäktigt. De andra två mäter graden av inflytande. Om arbetet inte är enformigt samt om den intervjuade svarat att han eller hon själv kan bestämma sin arbetstakt anses individen ha eget beslutsutrymme i arbetet. Enligt den s.k. krav-kontroll modellen för psykosocial arbetsmiljöbelastning (Karasek \& Theorell 1990) är den psykosociala arbetsmiljön dålig om arbetet innebär höga krav i kombination med låg grad av beslutsutrymme. Därför får denna variabel värdet ett om kraven är höga och individen inte har beslutsutrymme enligt definitionen ovan, annars noll.

Vi använder oss av fyra indikatorer på ohälsa, varav tre är indexbaserade. Den fjärde, "Allmän ohälsa", har kodats utifrån frågan »är ditt allmänna hälsotillstånd gott, dåligt eller något däremellan?», där de som svarade dåligt eller något däremellan har ansetts ha dålig hälsa och därmed fått värdet ett på variabeln. Övriga har kodats till noll. Det index som mäter psykiska besvär är baserat på sex frågor om psykiskt välbefinnande. De som angett att de har minst ett svårt, eller tre lätta besvär av allmän trötthet, sömnbesvär, nervösa besvär, depressioner respektive överansträngning, eller har rapporterat minst lätta besvär på frågan "har du under de senaste tolv månaderna haft psykisk sjukdom?", har fått värdet ett på variabeln "Psykiska problem", annars noll. Indexet för besvär av värk är baserat på frågor om värk i rörelseapparaten, dvs. värk i skuldror/axlar, värk i rygg/höfter, värk i händer, armbågar, ben eller knän, där de som har minst ett svårt eller tre lätta besvär har fått värdet ett på variabeln "Värk", annars noll. Slutligen mäts cirkulationsbesvär med ett index baserat på frågor om cirkulationssystemet, dvs. smärtor i bröstet, hjärtsvaghet, högt blodtryck och yrsel, där intervjupersoner med minst ett svårt eller tre lätta besvär, eller de som svarat minst ıja, lättı på frågan whar du under de senaste tolv månaderna haft hjärtinfarkt?", har fått värdet ett på variabeln "Cirkulation", annars noll.

Utöver socioekonomisk grupp, arbetsmiljö och ohälsa kommer vi i de multivariata analyserna även kontrollera för ålder. Det gör vi med en variabel som skiljer mellan åldersgrupperna 20-29, 30-39, 4049 och 50-59 år.

Eftersom vår utfallsvariabel långvarig sjukskrivning är dikotom, dvs. den kan bara anta två värden, förekomst eller inte förekomst av långtidssjukskrivning, har vi valt genomföra den statistiska analysen med hjälp av s.k. logistisk regressionsanalys. I den typen av regressionsmodell analyserar man sannolikheten eller oddset att befinna sig i en viss kategori (eller att en händelse ska inträffa). Oddset definieras som sannolikheten att befinna sig i en viss kategori dividerat med sannolikheten att inte befinna sig där. Resultaten redovisas som oddskvoter. Oddskvoten betecknar den relativa avvikelsen i odds jämfört med en referensgrupp som ges oddskvoten ett. Andra faktorer som ingår i analysen hålls 
samtidigt konstanta. Exempelvis skulle en oddskvot på 1,5 för kvinnor i en analys där män utgör referenskategori betyda att kvinnor har 50 procent högre odds än män för det aktuella utfallet oavsett värde på övriga faktorer som ingår i modellen.

Innan vi ger oss in på regressionsanalyserna redovisar vi dock hur den långvariga sjukfrånvaron fördelar sig över de socioekonomiska grupperna.

\section{Resultat}

Tabell 1 visar så den procentuella fördelningen av långvarig sjukfrånvaro (60 dagar eller mer) över de socioekonomiska grupperna för perioderna 1991-93 respektive 2000-02. Resultaten särredovisas för män och kvinnor. Om vi först betraktar mönstren för perioden 1991-93 så finner vi ett i stort sett förväntat klassmönster med högre tal för arbetare och lägre för tjänstemän. Liksom i Hemströms (2000) studie finner vi också att mönstret är tydligare för män än för kvinnor. Kvinnors sjukfrånvaro är som väntat högre totalt sett. Den största skillnaden mellan könen finner vi för tjänstemän på hög- och mellannivå.

Till perioden 2000-02 har andelen långtidssjukskrivna ökat för båda könen, men allra mest bland kvinnor. Det här speglar det som nämndes ovan om att gapet mellan kvinnors och mäns sjukfrånvaro har ökat under 1990- och 2000-talets "sjukfrånvarokris». Om vi betraktar procentandelarna i Tabell 1 som risker, kan vi konstatera att under den första perioden var kvinnors risk för långtidssjukskrivning, så som vi definierat begreppet, 55 procent högre än männens. Till den andra perioden har denna överrisk ökat till närmare 70 procent.

När det gäller klasskillnadernas utveckling över tid är det lite svårare att på ett enkelt sätt beskriva vad som händer. Om vi först tittar på kolumnerna för män och jämför ej facklärda arbetare med högre tjänstemän så framstår det som att klasskillna-

\section{Tabell I.}

Andelar (\%) med minst ett sjukfall om 60 dagar eller mer under 1991-93 respektive 2000-02 efter socioekonomisk grupp 1991 respektive 2000. Anställda män och kvinnor 20-59 år 1991 respektive 2000. Ninom parentes.

\begin{tabular}{|c|c|c|c|c|}
\hline & \multicolumn{2}{|c|}{ Män } & \multicolumn{2}{|c|}{ Kvinnor } \\
\hline & |99|-93 & $2000-02$ & 1991-93 & 2000-02 \\
\hline Ej facklärda arb. & $|3| \quad,(29 \mid)$ & I5,4 (338) & 19,6 (397) & 19,2 (344) \\
\hline Facklärda arb. & 13,6 (338) & I I,2 (347) & $10,3(156)$ & $20,5(185)$ \\
\hline Lägre tjm & $9,2(152)$ & II,8 (I53) & 15,2 (329) & 16,7 (299) \\
\hline Mellan tjm & $4,6 \quad(237)$ & 9,5 (306) & II,0 (29|) & 17,0 (389) \\
\hline Högre tjm & $4,4 \quad(250)$ & 3,9 (307) & $12,0(133)$ & $12,8(188)$ \\
\hline Totalt & $9,5(1268)$ & $\mid 0,3(|45|)$ & |4,7 (| 306) & $17,4(1405)$ \\
\hline
\end{tabular}


derna ökat eftersom det i den förstnämnda gruppen sker en ökning av andelen med 60 dagars sjukskrivning, medan det sker en minskning i den sistnämnda. Samtidigt talar dock utvecklingen i grupperna däremellan för minskade klasskillnader eftersom de största ökningarna sker bland lägre tjänstemän och tjänstemän på mellannivå, samtidigt som andelen långtidssjukskrivna minskar bland facklärda arbetare. Vi får alltså en ökning av skillnaden mellan klasstrukturens ändpunkter samtidigt som gränsen mellan arbetare och tjänstemän blir otydligare.

För kvinnorna är som nämnts dessa skillnader otydliga redan från början. Den största förändringen över tid sker för gruppen facklärda arbetare där andelen med långtidsfrånvaro fördubblas. Även för tjänstemän på mellannivå sker en påtaglig ökning. I princip kan man säga att det är inom de här två kategorierna som ökningen bland kvinnor sker. Om vi skulle ta bort dessa kategorier skulle kvinnors sjukfrånvaro vara i princip oförändrad.

Som framgår i tabellen är det förhållandevis få personer i varje kategori och detta gör att de procentsiffror som redovisas är statistiskt osäkra. Om vi sätter 90-procentiga s.k. konfidensintervall kring procentsatserna i Tabell 1 , så skulle vi se att det är få av de redovisade förändringarna som är statistiskt signifikanta. ${ }^{3} \mathrm{Av}$ de inom-

3 Detta trots att ett 90-procentigt konfidensintervall är ganska „tillåtande». Av utrymmesskäl redovisar vi inte konfidensintervallen här, men de kan göras tillängliga för den intresserade från författarna. Konfidensintervallen går dessutom att beräkna m.h.a. de uppgifter som redovisas i tabellen. gruppsliga förändringar vi diskuterat är det egentligen bara förändringen bland kvinnliga facklärda arbetare som är statistiskt signifikant i strikt mening. Förändringarna bland tjänstemän på mellannivå är dock på gränsen till signifikanta för både män och kvinnor. Könsskillnaderna är statistiskt signifikanta, däremot är ökningen för männen totalt inte signifikant och för kvinnorna är förändringen på gränsen till signifikant. När det gäller förändringar över tid för män och kvinnor totalt kan vi dock luta oss mot mängder av andra studier och statistiska redovisningar, från bl.a. Försäkringskassan, med betydligt större urval än här och tryggt dra slutsatsen att dessa förändringar de factoägt rum.

Sammanfattningsvis kan vi således utifrån Tabell 1 dra slutsatsen att för kvinnor har de klasskillnader som fanns under den första perioden i princip försvunnit till den andra. Kvinnliga högre tjänstemän ligger i och för sig i princip kvar på sin låga nivå, vilket skulle kunna tyda på en liknande tendens bland kvinnor som den vi sett för män. I kvinnornas fall är emellertid inte de högre tjänstemännens avvikelse signifikant jämfört med någon av de andra grupperna. Det finns inte heller i övrigt några statistiskt signifikanta skillnader mellan grupperna under period två. Detta har dock inte skett genom förbättringar bland dem med det sämsta utgångsläget utan genom en påtaglig försämring bland dem med bäst utgångsläge. För männen är mönstret lite mer tvetydigt. Den enda förändring som är åtminstone nästan statistiskt signifikant är den ökning som sker bland tjänstemän på mellannivå. Det vi kan konstatera utifrån Tabell 1 är ändå att det sker en utjämning 
bland de tre mellangrupperna. Ökningen bland ej facklärda arbetare är inte statistiskt signifikant och det är inte heller minskningen bland högre tjänstemän. Men i och med att de två övriga tjänstemannagrupperna ökar sin frånvaro något blir ändå slutresultatet att de högre tjänstemännen "förbättrarı sin position gentemot de andra grupperna. Under perioden 2000-02 avviker denna grupps procentvärde signifikant från samtliga övriga gruppers, vilket inte är fallet under den första perioden. För männen finner vi alltså två processer: dels en utjämning bland mellangrupperna, dels en utveckling som vi skulle kunna se som tecken på en polarisering där åtminstone den mest gynnade "extremen" hamnat i en än mer privilegierad position.

\section{Multivariata analyser}

För att gå vidare med våra frågeställningar och undersöka i vilken mån observerade köns- och klasskillnader kan förklaras med arbetsmiljö och ohälsa använder vi oss som sagt av logistisk regressionsanalys. Resultaten från dessa analyser redovisas i Tabell 2 och 3. I båda tabellerna gäller Modell 13 perioden 1991-93 och Modell 4-6 avser 2000-02. I samtliga modeller hålls effekten av ålder konstant.

Tabell 2 visar resultaten för män. I Modell 1 ser vi ett likartat mönster för den klassmässiga fördelningen av sjukfrånvarorisken som det $\mathrm{i}$ Tabell 1. Långtidssjukfrånvarons klassmässiga fördelning bland män går alltså inte att förklara med sammansättningseffekter avseende ålder. Klassmönstret består också i huvudsak oförändrat då vi kontrollerar för arbetsmiljöfaktorerna (Modell 2), även om skillnaderna minskar något (oddskvoterna närmar sig 1,0). En liten del av klassvariationen $i$ långtidssjukskrivning skulle alltså kunna tillskrivas skillnader i arbetsmiljö. Att arbetsmiljöfaktorerna i sig inte har något statistiskt signifikant samband med långtidssjukskrivning beror på att vi redan kontrollerar för ålder och SEI. Om vi endast inkluderar arbetsmiljöindikatorerna (med ålder) i modellen så finner vi tydliga effekter i förväntad riktning för ergonomisk och kemisk/fysisk belastning, däremot inte av psykosociala arbetsmiljöproblem. Arbetsmiljö har alltså betydelse för männens sjukfrånvaro, men den fångas upp av SEI-faktorn. ${ }^{4}$

I Modell 3 där hälsoindikatorerna införs minskar de två högre tjänstemannagruppernas avvikelse från referenskategorin ej facklärda arbetare något. Estimatet för högre tjänstemän är nu signifikant endast på 10-procentsnivån. Vi finner också tydliga effekter i förväntad riktning av alla ohälsoindikatorer förutom för psykisk ohälsa. Starkast effekt får variabeln "Allmän ohälsa» där de som uppgett att deras allmänna hälsotillstånd inte är helt bra har ca 3,5 gånger högre odds att ha en långvarig sjukskrivning åren närmast efter intervjun jämfört med dem som uppgett att deras allmänna hälsotillstånd är gott. ${ }^{5}$

4 När ohälsoindikatorerna inkluderas i en sådan modell reduceras effekten av arbetsmiljö. Endast en svag effekt av „Kemfys» återstår.

5 Här kan nämnas att de olika hälsomåtten i viss mån tar ut varandra. Det gäller i synnerhet "Allmän ohälsa» som i hög grad tränger ut effekterna av de övriga ohälsoindikatorerna. 
Även för perioden 2000-02 finner vi att klassmönstret inte avviker i någon nämnvärd utsträckning från det som visades $i$ Tabell 1 (Modell 4-6). Undantaget är att i regressionsmodellen är skillnaden mellan tjänstemän på mellannivå och ej facklärda arbetare signifikant vilket inte var fallet när vi bara tittade på den procentuella fördelningen. Trots det kan vi emellertid dra slutsatsen att inte heller under denna period kan klasskillnaderna bland män förklaras av ålderssammansättning. I nästa modell (Modell 5) framträder dock en skillnad jämfört med den tidigare perioden. Här

\section{Tabell 2.}

Resultat frän logistiska regressioner på oddset att ha minst ett sjukfall om 60 dagar under 1991-93 ( $n=1268$ ) respektive 2000-02 ( $n=1451)$. Anställda män 20-59 år 1991 respektive 2000. Samtliga modeller är kontrollerade för ålder. Oddskvoter.

\begin{tabular}{|c|c|c|c|c|c|c|}
\hline & \multicolumn{3}{|c|}{ 199|-93 } & \multicolumn{3}{|c|}{$2000-02$} \\
\hline & I & 2 & 3 & 4 & 5 & 6 \\
\hline \multicolumn{7}{|l|}{ SEI } \\
\hline Ej facklärda. arb. & I & I & I & I & I & I \\
\hline Facklärda arb. & 1,05 & 1,00 & $|| \mid$, & 0,70 & 0,73 & 0,74 \\
\hline Lägre tjm & 0,62 & 0,76 & 0,86 & 0,72 & 0,79 & 0,74 \\
\hline Mellan tjm & $0,28 * * *$ & $0,34 * *$ & $0,43 *$ & $0,55^{*}$ & $0,63^{+}$ & $0,62^{+}$ \\
\hline Högre tjm & $0,24 * * *$ & $0,3 \mid$ *** & $0,47^{\dagger}$ & 0,21 ***** & $0,24 * * *$ & $0,28 * * * *$ \\
\hline \multicolumn{7}{|l|}{ Arb. Miljö } \\
\hline Ergoi & & 1,25 & 1,03 & & ।,59* & 1,40 \\
\hline Kemfysi & & 1,36 & 1,22 & & 0,85 & 0,73 \\
\hline Psyki & & 1,08 & 0,84 & & $1,49^{\dagger}$ & 1,20 \\
\hline \multicolumn{7}{|l|}{ Hälsa } \\
\hline Allm. ohälsi & & & $3,42 * * *$ & & & $2,70 * * * *$ \\
\hline Psyk problï & & & 1,08 & & & $1,60+$ \\
\hline Värkii & & & $2,39 * * *$ & & & $2,20 * * * *$ \\
\hline Cirkulation"ii & & & $2,77 *$ & & & 1,14 \\
\hline Konstant & $0,10 * * *$ & $0,07 * * * *$ & $0,05 * * *$ & $0,14 * * * *$ & $0,10 * * *$ & $0,08 * * * *$ \\
\hline LLR & 34,81 & 3,50 & 74,44 & 29,64 & 8,82 & 69,75 \\
\hline df & 4 & 3 & 4 & 4 & 3 & 4 \\
\hline p-värde & $<0,00$ । & 0,321 & $<0,00$ । & $<0,00$ । & 0,032 & $<0,00$ । \\
\hline
\end{tabular}

$+\mathrm{p}<0,1 ;{ }^{*} \mathrm{p}<0,05 ;{ }^{* *} \mathrm{p}<0,01 ; \mathrm{p}<0,001$

i Ej exponerad utgör referenskategori

ii Ej hälsoproblem utgör referenskategori

Bäckman, Bryngelson \& Lundberg: Den ojämlika sjukfrånvaron 
är det mer tydligt så att klasskillnaderna i långtidssjukskrivning kan förstås som en skillnad i arbetsmiljöbelastning, även om högre tjänstemän fortsätter att ha ett signifikant lägre odds. Klasskillnaderna förblir dock oförändrade när ohälsoindikatorerna införs.
Dessutom finner vi här att ergonomisk belastning liksom psykosocial arbetsmiljöbelastning är kopplat till signifikant högre odds för långtidssjukskrivning även efter kontroll för SEI, men att dessa skillnader i sjukskrivning mellan människor med olika arbetsmiljö minskar vid kontroll för hälsa.

\section{Tabell 3.}

Resultat från logistiska regressioner på oddset att ha minst ett sjukfall om 60 dagar under 1991-93 ( $n=1$ 306) respektive 2000-02 ( $n=1405)$. Anställda kvinnor 20-59 år 1991 respektive 2000. Samtliga modeller är kontrollerade för älder. Oddskvoter.

\begin{tabular}{|c|c|c|c|c|c|c|}
\hline & \multicolumn{3}{|c|}{ 1991-93 } & \multicolumn{3}{|c|}{$2000-02$} \\
\hline & I & 2 & 3 & 4 & 5 & 6 \\
\hline \multicolumn{7}{|l|}{ SEI } \\
\hline Ej facklärda. arb. & I & । & I & I & I & I \\
\hline Facklärda arb. & $0,47 *$ & $0,48 *$ & $0,55^{\dagger}$ & 1,09 & $\mid, 01$ & 1,21 \\
\hline Lägre tjm & 0,73 & 1,03 & 1,10 & 0,84 & 0,90 & 0,97 \\
\hline Mellan tjm & $0,50 * *$ & 0,70 & 0,85 & 0,86 & 0,92 & 1,16 \\
\hline Högre tjm & $0,55^{*}$ & 0,81 & 0,93 & $0,62 *$ & 0,69 & 0,80 \\
\hline \multicolumn{7}{|l|}{ Arb.miljö } \\
\hline Ergo' & & $2,13 * * *$ & ।,74*** & & 1,17 & 0,95 \\
\hline Kemfysi & & $1,46^{\dagger}$ & $1,54^{\dagger}$ & & 1,37 & 1,22 \\
\hline Psyki & & $1,44^{\dagger}$ & 1,23 & & $1,42 *$ & $1,2 \mid$ \\
\hline \multicolumn{7}{|l|}{ Hälsa } \\
\hline Allm. ohälsii & & & $2,62 * * * *$ & & & $2,49 * * * *$ \\
\hline Psyk problii & & & $1,52^{\dagger}$ & & & ।,59* \\
\hline Värkii & & & $2,15 * * * *$ & & & $2,36 * * * *$ \\
\hline Cirkulationi" & & & 1,48 & & & 1,20 \\
\hline Konstant & $0,23 * * * *$ & 0,12 **** & $0,09 * * * *$ & 0,23 **** & $0,18 * * * *$ & 0,10 **** \\
\hline LLR & 14,06 & 29,23 & 77,24 & 5,05 & 10,58 & 112,02 \\
\hline$d f$ & 4 & 3 & 4 & 4 & 3 & 4 \\
\hline p-värde & 0,007 & $<0,00$ । & $<0,00$ । & 0,282 & 0,014 & $<0,00$ । \\
\hline
\end{tabular}

† $\mathrm{p}<0,1 ;{ }^{*} \mathrm{p}<0,05 ;{ }^{* *} \mathrm{p}<0,01 ; \mathrm{p}<0,001$

i Ej exponerad utgör referenskategori

ii Ej hälsoproblem utgör referenskategori 
Arbetsmiljöproblem som leder till långa sjukfall förefaller därmed ha blivit lite svagare kopplade till klassposition. Sambandet mellan arbetsmiljö och långa sjukfall tycks också främst gå via effekten på hälsotillståndet.

I Tabell 3 redovisas motsvarande modeller för kvinnor. Inte heller här kan vi se att åldersammansättning kan förklara något av klasskillnaderna. I det avseendet finns det alltså inga könsskillnader. Däremot finner vi könsskillnader när det gäller betydelsen av arbetsmiljö för klasskillnaderna - skillnaden mellan ej facklärda arbetare och tjänstemän på hög- och mellannivå kan till en inte obetydlig del förstås som en skillnad i arbetsmiljö. Skillnaden gentemot de facklärda arbetarna tycks däremot ha andra orsaker. Införandet av ohälsoindikatorerna i Modell 3 minskar klasskillnaderna ytterligare, även om skillnaden mellan ej facklärda och facklärda arbetare fortfarande är signifikant (dock endast på 10- procents nivån). Liksom för männen ger indikatorn på allmän ohälsa den starkaste effekten.

I Modell 4 upprepas mönstret från Tabell 1 för kvinnor, dvs. det finns inga egentliga klasskillnader förutom att högre tjänstemän har en något lägre risk för långa sjukfall. I Modell 5, när vi kontrollerar för arbetsmiljö, försvinner också denna signifikanta skillnad. Betydelsen av arbetsmiljö för sjukskrivning mer än 60 dagar, utöver den del som är klassbestämd, är liten och betydligt mindre under 2000-talets början än under den förra perioden. Här finner vi alltså motsatta utvecklingsmönster för män och kvinnor. Men som för männen verkar arbetsmiljöproblem i huvudsak inverka på sjukskrivningar genom ett försämrat hälsotillstånd.
För att sammanfattningsvis återknyta till våra inledande frågeställningar kan vi för det första konstatera att resultaten i våra analyser talar för att klassmönstret faktiskt har förändrats mellan de två undersökta perioderna på så sätt att klasskillnaderna tycks minska över tid. Undantaget i detta sammanhang är de manliga högre tjänstemännen vars skillnad gentemot övriga grupper ökar. I och med att klasskillnaderna minskar för både män och kvinnor kan vi också konstatera att könsskillnaderna härvidlag tenderar att minska. Skillnaden mellan män och kvinnor totalt ökar visserligen, men klassmönstren inom respektive grupp närmar sig alltså varandra. Vi kan också konstatera att effekterna av arbetsmiljöexponering har förändrats över tid. Detta sker dock på olika sätt för män och kvinnor då de sammantagna effekterna av dessa faktorer ökar något över tid för männen medan de minskar för kvinnorna.

När det gäller frågan om huruvida vi kan förklara klasskillnader endast med hänvisning till arbetsmiljö- respektive hälsoskillnader ger våra analyser det preliminära svaret att det kan vi inte helt. När vi för in arbetsmiljöfaktorerna i regressionsmodellerna ändras estimaten för de socioekonomiska grupperna ganska måttligt. Detsamma kan sägas om hur hälsofaktorerna påverkar de estimerade klasskillnaderna. Därmed kvarstår också klasskillnader i långa sjukfall bland män också efter kontroll för skillnader i arbetsmiljö och hälsa, även om det bara är tjänstemän på mellanoch högre nivå som avviker klart och statistiskt signifikant. Bland kvinnor är klassskillnaderna små redan från början, och klassmönstret också mindre tydligt, men 
de skillnader som finns kan ändå i påtaglig grad kopplas till skillnader $\mathrm{i}$ arbetsmiljö och hälsa.

\section{Diskussion}

Det mest övergripande resultatet av denna studie är att klasskillnaderna $i$ långvarig sjukskrivning tycks minska. Detta sker dock inte genom att de med sämst utgångsläge förbättrar sina positioner. Istället rör det sig om vad Bäckman och Edling (2000) kallar negativ konvergens, dvs. att åtminstone delar av de tidigare minst drabbade grupperna har haft en sämre utveckling än övriga och därmed närmar sig dessa. Det går därmed inte att påstå att den ökade sjukskrivning under 1990-talet bidragit till att öka den klassmässiga skiktningen i samhället. Därmed inte sagt att sjukskrivningsvågen inte kan ha bidragit till ökade skillnader i samhället. Men det har i så fall skett längs andra dimensioner. Den mest uppenbara av dessa är könsdimensionen. Skillnaden mellan mäns och kvinnors sjukfrånvaro har ökat och vi vet från andra studier att de dåliga prognoser för full återgång $i$ arbete som personer med omfattande sjukskrivning har är allra sämst för kvinnor (Socialstyrelsen 2006).

Bland kvinnor är också den negativa konvergensen som allra tydligast. De klasskillnader som fanns under den första av våra perioder, 1991-93, är i det närmaste utraderade till den andra perioden, 2000-02. Facklärda arbetare och tjänstemän på mellannivå som under 1991-93 hade ungefär hälften så stort odds för långvarig sjukskrivning som ej facklärda arbetare, hade under
2000-02 kommit upp i samma nivå som de senare. Vi vet att bland kvinnor domineras dessa grupper av anställda inom välfärdstjänstesektorn. Det handlar om yrkesgrupper som undersköterskor, barnskötare, lärare och sjuksköterskor, för vilka tidigare studier visat en påtagligt försämrad psykosocial arbetsmiljö under 1990-talets andra hälft (t.ex. Bäckman 2001).

För männen har vi inte kunnat förklara mer än en del av de klasskillnader som trots allt finns med våra arbetsmiljö- och ohälsoindikatorer. Självklart ligger en del av förklaringen i att vi rimligen inte täcker in alla aspekter av arbetsmiljö och ohälsa med hjälp av våra indikatorer. Samtidigt har det uppenbarligen också hänt något substantiellt under 1990-talet eftersom vi med samma variabler kan förklara betydligt mindre av klassvariationen $i$ långa sjukfall 2000-02 än för 1991-93. Andra faktorer än klasskillnader i arbetsmiljö och hälsa verkar därmed ha kommit att spela en större roll för klasskillnaderna i sjukfall längre än 60 dagar, men vilka dessa faktorer är säger våra analyser förstås inget om.

Möjligheterna att dra definitiva slutsatser från en analys som denna begränsas förstås av olika metodproblem och begränsningar. En sådan är att Levnadsnivåmaterialet i detta sammanhang inte är stort nog, vilket får till följd att antalet personer med långa sjukfall blir litet och osäkerheten i skattningarna av andelar och samband större än önskvärt. Även om materialet är rikt på uppgifter om både arbete och hälsa är det också så att arbetsförmågan endast fångas indirekt med de indikatorer som står till vårt förfogande. Därmed finns det således utrymme för variationer i fak- 
tisk arbetsförmåga mellan klasser som inte fångas in i vår analys, och som kan bidra till att variationerna i sjukskrivning mellan klasserna inte helt kan förklaras i våra analyser. Dessutom finns det förstås också mätfel i såväl våra arbetsmiljöindikatorer som våra hälsoindikatorer.

Ytterligare en begränsning när det gäller generaliserbarheten av resultaten är att vi endast följer LNU-individernas sjukskrivningar fram t.o.m. 2002. Det skulle kunna hävdas att det sedan dess gått så pass lång tid att våra resultat inte längre gäller. Mot ett sådant påstående talar dock det faktum att sjukfrånvarouppgången nådde sin kulmen 2002 och sjuktalen har sedan dess legat ganska still. Vi vet också att könsskillnaderna inte förändrats sedan dess (http:// statistik.forsakringskassan.se).

Men om våra resultat därmed bör granskas kritiskt och följas upp med andra studier, kan de samtidigt bidra till en nödvändig diskussion om hur välfärdsstatens institutioner, här i formen av sjukförsäkringen, bäst organiseras för att kunna utgöra de kollektiva resurser som de är tänkta att vara. Hur ska vi utifrån en sådan utgångspunkt förstå våra fynd? För det första är det viktigt att konstatera att sjukförsäkringen, liksom sjukvård, är en resurs de flesta helst inte vill utnyttja, men som utgör ett viktigt skydd mot inkomstförlust för dem som inte klarar att arbeta p.g.a. sjukdom, och därmed även en trygghet för dem som inte utnyttjar försäkringen. På detta sätt fungerar sjukförsäkringen som andra, t.ex. en brand- eller hemförsäkring - helst vill vi att det inte blir inbrott eller eldsvåda, men om vi ändå drabbas av något sådant ger försäkringen ett skydd mot den ekono- miska skadan. Sjukförsäkringen är därmed en potentiell resurs för alla på arbetsmarknaden, och att den är allmän och skattefinansierad medför att den även inkluderar människor som annars inte hade varit försäkringsbara.

Vi finner därmed också skillnader i sjukskrivning så som man kan förvänta sig med kännedom om de klassmässiga skillnaderna i arbetsmiljö och hälsa, samtidigt som dessa skillnader inte tycks vara tillräckliga förklaringar. Det är utifrån analyserna vi gjort här inte möjligt att säga om de kvarstående skillnaderna är ett uttryck för növersjukskrivning" bland arbetargrupperna eller "undersjukskrivning" bland tjänstemännen. En möjlig orsak kan vara skillnader i arbetsmiljö som vi inte lyckas fånga med våra indikatorer. Framför allt har de högre tjänstemännens och i viss mån "mellantjänstemännen" en flexibilitet både vad gäller arbetstider, arbetsuppgifter och var man faktiskt utför sina arbetsuppgifter som vi inte fångar med våra arbetsmiljöindikatorer. Har man möjlighet att arbeta hemma kan det göra eventuell »sjuknärvaro« mindre skadlig, vilket i sin tur kan ha en dämpande effekt på risken för långvarig sjukskrivning. Mot bakgrund av den negativa utvecklingen av den psykiska hälsan finns det anledning att tro att den typen av arbetsvillkor blivit alltmer avgörande för skillnader i sjukfrånvarorisker mellan olika grupper. Studier inom ramen för den s.k. sjukflexibilitetsmodellen visar också att liknande typer av flexibilitet har en dämpande effekten på risken för sjukskrivning samtidigt som det ökar chansen bland redan sjukskrivna att återkomma i arbete (Johansson \& Lundberg 2004, Johansson et al. 2006). I vilken 
mån detta kan förklara högre tjänstemäns lägre sjukfrånvaro är emellertid outrett och ytterligare forskning behövs därför för att räta ut dessa frågetecken. Vad denna studie visar är att det i alla fall inte beror på skillnader i arbetsmiljö i traditionell bemärkelse. När det gäller kvinnliga högre tjänstemän tycks det dock vara så att just sådana traditionella aspekter av arbetsmiljön förklarar större delen av deras lägre sjukfrånvarorisker.

En annan möjlig förklaring skulle kunna vara skillnader i belastning utanför arbetet. Många livsvillkor varierar mellan samhällsklasser och skapar därmed inte enbart skillnader i hälsa och funktionsförmåga, utan även skillnader i möjligheterna att hantera sådana hälsoproblem. Att skillnader i långtidssjukskrivning skulle kunna förstås som ett utslag av systematiska skillnader i fusk med socialförsäkringen är därmed mindre troligt, åtminstone om vi med fusk menar sjukanmälningar utan egentligt nedsatt arbetsförmåga.

Avslutningsvis är det enligt vår mening viktigt att de välfärdspolitiska institutioner som skapats för att utgöra en resurs för medborgarna också fungerar så. Det finns dock en risk att den ökning av långtidssjukskrivningarna som skett allra mest tydligt bland kvinnliga facklärda arbetare är ett symptom på att sjukförsäkringen för vissa grupper förvisso förhindrar fattigdom, men samtidigt hotar att bidra till marginalisering och utslagning från arbetsmarknaden istället för att rehabilitera människor tillbaka till arbete. I denna artikels inledning påpekade vi att rehabiliteringen av långtidssjukskrivna kanske inte fungerar som den borde och att detta i så fall framför allt drabbar redan svaga grupper. Uppenbarligen är det så att rehabiliteringsinsatserna inte ökat i samma takt som långtidssjukskrivningarna (Försäkringskassan 2005 s. 168), vilket får ses som ett stöd för den tesen. Utifrån Försäkringskassans egen statistik kan man också utläsa att män tycks få mer omfattande rehabiliteringsinsatser än kvinnor (a.a.s. 169). Om denna bild stämmer fungerar i det här fallet inte den idealtypiska bild som målades upp i inledningsavsnittet om att de som missgynnas av marknadens resursfördelning (t.ex. facklärda kvinnliga arbetare) kompenseras av statens mer jämlika resursfördelning. Huruvida denna tolkning är korrekt eller inte går förstås inte att utläsa ur de analyser vi presenterat här. Men sjukförsäkringens organisation och resultat bör diskuteras utifrån i vilken grad den de facto utgör en resurs för medborgarna. Med ett sådant perspektiv för ögonen blir också de mänskliga snarare än de statsfinansiella konsekvenserna av brister i systemens funktion den naturliga utgångspunkten. 


\section{Referenser}

Bryngelson, A. (2007) "Social exclusion and sickness absence". Manuskript. Stockholm: CHESS, Stockholms universitet.

Bäckman, O. (1998) Longitudinal studies on sickness absence. Institutets för Social Forskning avhandlingsserie $\mathrm{nr}$ 34. Stockholm: Stockholms universitet.

Bäckman, O. (2001) "Med välfärdsstaten som arbetsgivare-arbetsmiljön och dess konsekvenser inom välfärdstjänstesektorn på 1990-talet». I M. Szebehely (red.) Välfärdstjänster i omvandling. Delbetänkande/Kommitén Välfärdsbokslut. SOU 2001:52. Stockholm: Fritzes.

Bäckman, O. \& Edling, C. (2000) „Arbetsmiljö och arbetsrelaterade besvär under 1990-talet". I S. Marklund (red.) Arbetsliv och hälsa 2000. Solna: Arbetarskyddsstyrelsen \& Arbetslivsinstitutet.

Fritzell, J. \& Lundberg, O. (2000) Välfärd, ofärd och ojämlikhet. Delbetänkade/Kommittén Välfärdsbokslut. SOU 2000:41. Stockholm: Fritzes.

Fritzell J., Gähler M. \& Lundberg O. (red.) (2001) Välfärd och arbete $i$ arbetslöshetens airtionde. SOU 2001:53. Stockholm: Fritzes.

Försäkringskassan (2005) Socialförsäkringsboken 2005. Stockholm: Försäkringskassan.

Hemström, Ö. (2000) "Klasskillnader i ohälsa och dödlighet«. I S. Marklund (red.) Arbetsliv och hälsa 2000. Solna: Arbetarskyddsstyrelsen \&
Arbetslivsinstitutet.

Johansson, G. \& Lundberg, I. (2004) »Adjustment latitude and attendance requirements as determinants of sickness absence and attendance. Empirical tests of the illness flexibility model «. Social Science and Medicine vol. 58, pp. 18571868.

Johansson G., Lundberg O. \& Lundberg I. (2006) "Return to work and adjustment latitude among employees on long-term sickness absence». Journal of Occupational Rehabilitation vol. 16, pp. 185-195.

Johansson, S. (1970) Om levnadsnivåundersökningen. Stockholm: Allmänna förlaget.

Karasek, R. A. Jr. \& Theorell, T. (1990) Healthy work. Stress, productivity, and the reconstruction of working life. New York: Basic Books.

Nicholson, N. (1977) "Absence behaviour and attendance motivation: a conceptual synthesis". Journal of Management Studies vol. 14, pp. 231-252.

Oscarsson, H. (2005) "Långsiktiga värdetrender». I S. Holmberg. \& L. Weibull (red.), Lyckan kommer, lyckan går. SOM-rapport nr 36. Göteborg: SOM-institutet.

Socialstyrelsen (2005) Folkhälsorapport 2005. Stockholm: Socialstyrelsen.

Socialstyrelsen (2006) Social rapport 2006. Stockholm: Socialstyrelsen.

Bäckman, Bryngelson \& Lundberg: Den ojämlika sjukfrånvaron 


\section{Summary}

\section{The inequity of sickness absence Class and gender differences in sickness absence in the 1990s and 2000s}

Between the years 1996 and 2003 sickness absence rates in Sweden increased tremendously. This development has been the spark for a sometimes intensive debate on its causes and consequences. Against this background it is surprising that we know so little about the socio-economic distribution of sickness absence rates. This article aims at filling this gap in our knowledge about the structure of sickness absence taking in Sweden. We analyse data from the Level of Living Surveys for 1991 and 2000 that have been linked to registry data covering sickness absence spells as registered by the Social Insurance Agency. By analysing the two cross-sectional data sets we get both a picture of the state in these two periods, but also of the development of the socio-economic distribution of absence rates. We direct special attention to gender differences in this respect.

The analyses show that the socio-econo- mic differences in sickness absence rates are more pronounced among men than among women and that these differences decrease between the two periods for both sexes. However, this tendency is not due to an improvement for those worst off from the start. Instead we find that it is groups that used to be well off in this respect, i.e. white-collar workers, whose position deteriorates. In the multivariate analyses we try to explain socio-economic differences statistically by investigating the impact of work environment and health factors. While these factors account for part of the class gradient, there are still significant class differences in long-term sickness absence among men also after control for work environment and health. Among women class differences are smaller and the class pattern less pronounced, but the differences found are to a larger extent linked to work environment and health. 